\title{
Illocutionary Acts Used by Indonesian Athletes in Instagram Caption in Asian Games 2018
}

\author{
Nisa Anggraini Batubara \\ Universitas Sumatera Utara, Indonesia \\ Email: nisaanggraini.batubara@gmail.com \\ Deliana \\ Universitas Sumatera Utara, Indonesia \\ Parlindungan Purba \\ Universitas Sumatera Utara, Indonesia
}

\begin{abstract}
This research aims to describe the types of illocutionary acts used by Indonesian athletes in Instagram caption in Asian Games 2018, and to find out the type of illocutionary acts which is mostly used by the Indonesian athletes. This research used descriptive qualitative method. The source of data is the Instagram accounts used by Indonesian Asian Games Athletes. The data are in the form of Indonesian athletes' 24 written utterances and categorized into types of illocutionary act based on Yule's theory. Based on data analysis, the finding shows there are four types of illocutionary acts used by Indonesian athletes in Instagram caption in Asian Games 2018, namely representatives (14), expressives (7), directives (2), and commissive (1). Representative is mostly used by Indonesian athlete in Instagram caption in Asian Games 2018.
\end{abstract}

Keywords: illocutionary acts, Instagram caption, Indonesian athletes

\section{INTRODUCTION}

Athletes as the social creature do the communication as well as human beings. The communication could be done through social media. As the development of technology, social media becomes famous in this era. The athletes have a role not just to themselves but also they have role as the influencers. In Instagram, they post photo with the caption that represents it. The caption contains what they think, they feel, they believe, their achievement, principle and condition. Moreover, they were competed in Asian Games 2018 that attract many eyes of the people. Therefore, the caption they wrote not just a caption. It is not only words. As Yule (1996, p. 47) said, "in attempting to express themselves, people do not only produce utterances containing grammatical structures and words, they perform actions via those utterances." Then called as illocutionary acts.

Yule (1996) classified types of illocutionary act into five, they are declarations, representatives, expressives, directives and commissives. In performing illocutionary act, the speaker should utter utterance with intended meaning to the hearer based on the situation and real conditi- on. By studying illocutionary act, it can help us to know more knowledge in understanding the speaker utterance in certain situation.

Since a caption contains utterance, then it is worthy to analyze the illocutionary acts of Instagram captions, in this case the Instagram captions that used by Indonesian athletes in Asian Games 2018, in order to describe the Indonesian athletes intention when they are performing utterances.

There are two points to be discussed in this research. First is the types of illocutionary acts used by Indonesian athletes in Instagram caption in Asian Games 2018 and the second is the most dominant type that used by Indonesian athletes.

Theoretically, this research hopefully will enrich the knowledge of the reader about the field of pragmatics, especially about the use of illocutionary act in the Instagram caption. Practically, this research is expected to provide insight to the readers in learning pragmatic field, especially about speech act.

\section{LITERATURE REVIEW}

Pragmatics

Yule (1996, p. 3) explains that pragmatics 
concern with some areas. Pragmatics is concerned with the study of meaning as communicated by a speaker (or writer) and interpreted by a listener (or reader). It has, consequently, more to do with the analysis of what people mean by their utterances than what the words or phrases in those utterances might mean by themselves.

The pragmatics analyzes how that language performs an action. How people may interact and keep using the language because there is action after using the language. It means that the language uttered has specific meaning with a particular purpose that the speakers intended to do something after the message delivered. That it is called as speech acts.

According to Searle, Speech act is a basic unit of communication, it suggests that there are a series of an analytic connection between the notion of speech acts, what the speaker means, what the sentence uttered means, what the speaker intends, and what the hearer understands. (Searle, 1969 as cited in Schiffrin, 1995, p. 90). Mey (1993) also puts his opinion about speech act as he says, "Simply stated, the central tenet of speech act theory is that the uttering of a sentence is, or is part of, an action within the framework of social institutions and conventions. Put in slogan form, saying is (part of) doing, or words are (part of) deeds".

In general, speech acts are acts of communication. To communicate is to express a certain attitude, and the type of speech act is performed corresponds to the type of attitude being expressed. For example, a statement expresses a belief, a request expresses a desire, and an apology expresses a regret. As an act of communication, a speech act succeeds if the audience identifies, in accordance with the speaker's intention, the attitude being expressed.

In relation to the types of speech act, some experts classify them into locutionary act, illocutionary act, and perlocutionary act. They are Austin (1962, pp. 98-99), Searle (1985, p. 11), Leech (1983, p. 199), Yule (1996, p. 48), Mey (1993, pp. 95-96) and Levinson (1983, p. 236).

Yule in his book (1996, p. 48) states that on any occasion, the action performed by producing an utterance will consist of three related acts such as:

Locutionary act, which is the basic act of utterance, or producing a meaningful linguistic expression.

Illocutionary acts is an act that performed via communicative force of an utterance.

Perlocutionary act is an act that simply creates an utterance with a function without inten- ding it to have an effect.

According to Austin's original exposition in "How to Do Things with Words" (1962), an illocutionary act is an act (a) for the performance of which a speaker must make it clear to some other person that the act is performed and (b) the performance of which illocutionary acts have to do with understanding they a involves the production of what Austin call "conventional consequences" as e.g., rights, commitments, or obligations. Therefore, for example, in order to successfully perform a promise, a speaker must make clear to his or her audience that the promise occurs, and undertake an obligation to do the promised thing, hence, promising is an illocutionary act in the present sense.

According to Searle (1969, p. 58), the illocutionary act is an act performed in saying something and a force indicating devices for commitment. For example, when a speaker says to a listener "I promise" and "I hereby promise", there is a strong difference in between them. The sentence "I hereby promise" will have a stronger meaning, and the listener will be more convinced to the speaker's utterance.

Many linguists made their own certain classification of illocutionary act based on careful examination. The first linguist who defined the classification was Austin. Austin (1962) distinguished between five classes by which all performative speech acts could be classified according to what it is that the act of uttering is meant to achieve. So, in essence, Austin set limitations as to the number of possible performative utterance types. These utterance types were Verdictives, Exercitives, Commissives, Behabitives, and Expositives. Austin suggested these classes with the forewarning that some fresh classification could be implemented in the future since his definitions were troublesome and prone to overlap.

Searle (1962), one of Austin's students who also studied language, goes further than Austin in providing not only the needed general framework for a theory of speech acts but also a richer specification of the detailed structures of speech acts themselves. Thus he distinguishes two kinds of felicity conditions: conditions on the performance of a speech act and conditions on its satisfaction (you need to fulfill the first in order to issue a promise and the second in order to keep your promise). Conditions on performance are divided still further into preparatory, propositional, sincerity and essential conditions. Five classifications of speech act delivered by Searle are assertive, directive, commissive, expressive, and declarative.

Yule (1996, p. 53) also defines five classifi- 
cations of speech act which not too much different from the recent. Then, this Yule's own that used in this thesis. The five classifications are declarations, representatives, expressives, directives, and commissives.

Declarations are those kinds of speech acts that change the world via their utterance. As the examples in (1) illustrate, the speaker has to have a special institutional role, in a specific context, in order to perform a declaration appropriately.

1. a. Priest: I now pronounce you husband and wife.

b. Referee: You're out!

c. Jury Foreman: We find the defendant guilty. In using a declaration, the speaker changes the world via words.

Representatives are those kinds of speech acts that state what the speaker believes to be the case or not. Statements of fact, assertions, conclusions, and descriptions, as illustrated in (2), are all examples of the speaker representing the world as he or she believes it is.

2. a. The earth is flat.

b. Chomsky didn't write about peanuts.

c. It was a warm sunny day.

In using a representative, the speaker makes words fit the world (of belief).

Expressives are those kinds of speech acts that state what the speaker feels. They express psychological states and can be statements of pleasure, pain, likes, dislikes, joy, or sorrow. As illustrated in (3), they can be caused by something the speaker does or the hearer does, but they are about the speaker's experience.

3. a. I'm really sorry!

b. Congratulation!

c. Oh, yes, great, mmmm, ssahh!

In using an expressive, the speaker makes words fit the world (of feeling).

Directives are those kinds of speech acts that speakers use to get someone else to do something. They express what the speaker wants. They are commands, orders, requests, suggestions, and as illustrated in (4), they can be positive or negative.

4. a. Give me a cup of coffee. Make it black.

b. Could you lend me a pen, please?

c. Do not touch that.

In using a directive, the speaker attempts to make the world fit the words (via the hearer).

Commissives are those kinds of speech acts that speakers use to commit themselves to some future action. They express what the speaker intends. They are promises, threats, refusals, pledges, and, as shown in (5), they can be perfor- med by the speaker alone, or by the speaker as a member of a group.

5. a. I will be back.

b. I'm going to get it right next time.

c. We will not do that.

In using a commissive, the speaker undertakes to make the world fit the words (via the speaker).

According to Peccei (1999, p. 56), felicity conditions are sets of necessary conditions for illocution to count. Yule (1996, p. 50-51) also explains that there are some conditions on speech acts in people performance. They are general conditions, content conditions, preparatory conditions, sincerity conditions and essential conditions.

\section{METHODOLOGY}

This research used descriptive qualitative method. The data used in this research are 24 written utterances in Indonesian athletes' Instagram captions in the period of Asian Games 2018 (19 August - 2 September 2018). The source of data in this research is Indonesian athletes' Instagram accounts. There are 24 accounts from 24 users who are Indonesian athletes in Asian Games 2018. They represent every sport that wins a medal. They are@dianandach (Archery), @ emilianovanv (Athletics), @greyspolii (Badminton),@sunanagung_(Boxing),@ramlabahar21 (Canoeing), @lasuthenky (Contract bridge), @ khoifulmukhib52 (Cycling), @rifdairfana (Gymnastics), @aqsaaswar (Jet Ski), @zigizaresta (Karate), @khasanins (Kurash), @hparadigma (Paragliding), @hanifan_yk (Pencak Silat), @ nyimasbungacinta (Roller Sports), @ginanjaredwin (Rowing), @rezki.djaina (Sepak Takraw), @muhammadtera (Shooting), @elbertsie_(Soft Tennis), @abudzar_firlyazri (Sport Climbing), @defiarosmaniar (Taekwondo), @christorungkat (Tennis), @ekopower62 (Weightlifting), @ condrodab (Volleyball), and @lindswell_k(Wushu).

Data collection can be divided into 4 types: observation, questioner, interview, and study of document (Miles, Huberman and Saldana, 2014, p. 46). In this research, the researcher used the study of document.

\section{RESULTS AND DISCUSSION}

Types of Illocutionary Acts used by Indonesian Athletes in Instagram Caption in Asian Games 2018 


\section{Representatives}

Representatives are those kinds of speech acts that state what the speaker believes to be the case or not. (Yule, 1996). They can be statements of fact, assertions, conclusions, and descriptions. Based on the research results, there are 14 data found as representatives. A sample of utterance that belongs to representatives type use by Indonesian athletes in the Instagram caption below.

\section{Data 1}

\section{@defiarosmaniar: We made history}

Context: The caption is written on August $23^{\text {rd }}, 2018$ by Defia Rosminar, from Taekwondo who got a gold Medal in Women's individual poomsae in Asian Games 2018. She stood on the podium and the Indonesian President, Mr. Joko Widodo put the medals on her neck, as the picture she posted with the above caption.

The Data 1 contains representative act. From the utterance "we made history", the athlete conveys her belief that Indonesia made one more history from her achievement that got a gold medal. She showed the gold medal and she tried to convience Indonesian people that Indonesian made history. She utters it in the statement of assertion.

\section{Expressives}

Expressives are those kinds of speech acts that state what the speaker feels. (Yule, 1996). They can be statements of pleasure, pain, likes, dislikes, joy, or sorrow. Based on the research results, there are 7 data found as expressives. A sample of utterance that classified as expressives use in the Instagram caption written by an Indonesian athlete below.

\section{Data 18}

@ginanjaredwin: Thank you for the memories!

Context: The caption was written on August $29^{\text {th }}, 2018$ by Edwin Ginanjar Rudiana, from Rowing who got a silver Medal in Men's quadruple sculls in Asian Games 2018. He and his rowing team took a picture together, wearing the silver medals in their necks, as showed by the picture that he posted with the caption above.

The Data 18 contains expressives act. From the utterance "thank you for the memories", the athlete expresses his pleasure, his feeling that he thanks to his team, and also to the chance that he had in Asian Games 2018, all of them created the memories for his life. The word "thank you" also indicates the caption as expressives type. In writing the utterance, the athlete intends to express gratitude.

\section{Directives}

Yule (1996) states directives are kind of illocutionary act that attempts by the speaker to get the hearer to do something. Based on the research results, there are 2 data found as directives. A sample of utterance that belongs to directives type written by Indonesian athletes in Instagram caption in Asian Games 2018 below.

Data 22

@emilianovanv : Trust the process!

Context: The caption was written on September $7^{\text {th }}, 2018$ by Emilia Nova, from Athletics who got a silver Medal in Women's 100 metres hurdles in Asian Games 2018. She was in the racing, as showed by the picture that she posted with the caption above.

The Data 22 contains directives act. From the utterance "trust the process", the athlete writes the utterance to get the Indonesian people to trust the process in their life. She suggests people to always trust the process that the result will be in line with the process that we pass. The typical structure of expression which is usually in imperative structure with the word referring to the imperative "trust" with verb initiating the utterance, also indicates the utterance as the directives type.

\section{Commissives}

Yule (1996) states commissives are kind of illocutionary act that is commit the speaker to some future course of action. In this research, there is 1 utterance that identified as commissives.

\section{Data 24}

@aqsaaswar: Bronze for today, Sunday will be better I promise.

Context: The caption was written on $\mathrm{Au}-$ gust $24^{\text {th }}, 2018$ by Aqsa Sutan Aswar, from Jet Ski who got gold and bronze medals in Endurance runabout open and Runabout limited in Asian Games 2018. He posted a flyer of himself from Asian Games 2018 showing his picture with the information about his wining.

The Data 24 contains commissive act. From the utterance, the athlete intends to make a promise that could also be indicated by the Illocutionary Force Indicating Device "will" and "promise". He promises to the Indonesian supporter that he will get better in the future, not just getting bronze, but silver and gold. The statement "bronze for today" is a supporting statement before the athlete utters the intended act namely commissives acts in his caption. Because he got 
a bronze medal, he promised to get the higher one. He commits in the next competition he will achieve the better achievement and automatically it indicates a promising function, which is a written or spoken declaration that one will definitely give or do or not something. The athlete genuinely intends to carry out future action.

\section{Declarations}

Declarations are said to bring about a change in reality: that is to say, the world is in someway no longer the same after they have been said. In using a declaration, the speaker changes the world via words and the speaker has to have a

Table 1. The types of illocutionary acts used by Indonesian athletes in Instagram caption in Asian Games 2018

\begin{tabular}{|c|c|}
\hline $\begin{array}{l}\text { Illocutionary Act } \\
\text { Types }\end{array}$ & Written Utterance (Caption) \\
\hline \multirow[t]{14}{*}{ Representatives } & (1) @defiarosmaniar: We made history \\
\hline & (2)@hanifan_yk: show time to gets our gold medals. \\
\hline & $\begin{array}{l}\text { (3) @ christorungkat: Batik is one of Indonesia's heritage that we should pre- } \\
\text { serve. Every detail of the motive has the deep meaning. Hard work, tenacity, } \\
\text { and persistence. This is what i use when practicing and competing for Indone- } \\
\text { sia. }\end{array}$ \\
\hline & $\begin{array}{l}\text { (4) @ khoifulmukhib52: The process to become the champion Indonesia asian } \\
\text { games } 2018\end{array}$ \\
\hline & (5) @rifdairfana: And This is where the story become history. \\
\hline & (6) @rezki.djaina: My team... \\
\hline & (7)@sunanagung_: Hard work Easy work \\
\hline & (8) @lindswell_k: 18 ${ }^{\text {th }}$ Asian Games 2018 medals \\
\hline & (9) @zigizaresta: Pain is temporary, greatness is forever! \\
\hline & $\begin{array}{l}\text { (10) @greyspolii: Everytime i play in team event. I don't play for myself but i } \\
\text { play for my team, I love my girls }\end{array}$ \\
\hline & $\begin{array}{l}\text { (11) @lasuthenky: Try out dan training camp menghadapi Asian Games } 188 \\
18\end{array}$ \\
\hline & (12)@nyimasbungacinta: Bismillah Today is The Day.... \\
\hline & (13)@muhammadtera: Pround \\
\hline & (14)@ekopower62 : Slow but sure untuk \#asiangames2018 snatch 140 \\
\hline \multirow[t]{7}{*}{ Expressives } & $\begin{array}{l}\text { (15)@abudzar_firlyazri: Time to back home... mission clear... Thanks to Allah } \\
\& \text { all... thanks for everything }\end{array}$ \\
\hline & (16) @khasanins: Thank you LIN-NING for support for us \\
\hline & $\begin{array}{l}\text { (17)@hparadigma: Alhamdulillah.... } \\
\text { Allah love me so much... Allah still open one of } d \text { jannah door for me... I hope } \\
\text { I can make them happy }\end{array}$ \\
\hline & (18)@ginanjaredwin: Thank you for the memories! \\
\hline & (19)@ramlabahar21: Alhamdulillah silver medals \\
\hline & (20)@dianandach : GoodLuck \\
\hline & $\begin{array}{l}\text { (21) elbertsie_: The man who introduce me to Soft Tennis. Thank you Mas @ } \\
\text { simpatiaji }\end{array}$ \\
\hline \multirow[t]{2}{*}{ Directives } & (22)@emilianovanv: Trust the process! \\
\hline & (23)@condrodab: Love your passion \\
\hline Commisives & (24)@aqsaaswar: Bronze for today. Sunday will be better I promise. \\
\hline Declarations & - \\
\hline
\end{tabular}


special institutional role, in a specific context, in order to perform a declaration appropriately since it deals with a special authority or institution such as declaring war, naming, and the like. For those reasons, on athlete's Instagram captions, declaration is not used. The analysis of 24 data which have been classified presented in Table 1 .

From the classification of the data Table 1 , it can be seen that there are four types of illocutionary acts found in Indonesian athletes' Instagram caption. They are representatives (14), expressives (7), directives (2) and commissives (1). While there is no declaration found in the data. Representatives is the most dominant type used by Indonesian atheletes in Instagram caption in Asian Games 2018. This was used since the Indonesian athletes utter many statements of facts, information, assertions, and descriptions about Asian Games 2018 in their captions due to they themselves who experience Asian Games 2018 directly. They share the moments, the stories and the beliefs that they kept during Asian Games 2018 to Indonesian people.

\section{CONCLUSION}

After analyzing the illocutionary acts used by Indonesian athletes in caption of Instagram in Asian Games 2018, the researcher comes to the following conclusion. There are four types of illocutionary acts found in the athletes' Instagram captions in the period of Asian Games 2018. They are representatives (14), expressives (7), directives (2) and commissives (1). While there is no declaration used by Indonesian athletes. From the total of the data above, representatives is the most dominant type that used by Indonesian athletes in Instagram caption in Asian Games 2018 since the athletes utter many statements of facts, information, assertions, and descriptions about Asian Games 2018 in their captions due to they themselves who experience Asian Games 2018 directly. They share the moments, the stories and the beliefs of Asian Games 2018 to Indonesian people.

\section{REFERENCES}

Austin, J. L. (1962). How to do Things with Word. Oxford: Oxford University Press.

Leech, G.N. (1983). Principles of Pragmatics. London: Longman Group Limited.

Levinson, S.C. (1983). Pragmatics. Cambridge: Cambridge University Press.

Mey, J.L. (1993). Pragmatics an Introduction. Oxford: Oxford University Press.

Miles M.B., Huberman, M.A., \& Saldana, J. (2014). Qualitative data analysis. London: Sage Publication.

Peccei, J.S. (1999). Pragmatics. London: Routledge.

Schiffrin, D. (1995). Approaches to Discourse. Cambridge: Blackwell.

Searle, J.R. (1969). An Essay in the Philosophy of Language. Cambridge: Cambridge University Press.

Searle, J.R (1962). Meaning and Speech Acts. Philosophical Review 71 (4):423-432.

Searle, J.R. (1985). Expression and Meaning: Studies in the Theory of Speech Acts. Cambridge: Cambridge University Press.

Yule, G. (1996). Pragmatics. Oxford: Oxford University Press. 